Article

\title{
Undariopsis peterseniana Promotes Hair Growth by the Activation of Wnt/ $\beta$-Catenin and ERK Pathways
}

\author{
Jung-Il Kang ${ }^{1}$, Min-Kyoung Kim ${ }^{1}$, Ji-Hyeok Lee ${ }^{2}$, You-Jin Jeon ${ }^{2,3}$, Eun-Kyoung Hwang ${ }^{4}$, \\ Young-Sang Koh 1,5, Jin-Won Hyun ${ }^{1,5}$, Soon-Young Kwon ${ }^{1}$, Eun-Sook Yoo ${ }^{1}$ and \\ Hee-Kyoung Kang 1,5,* \\ 1 Department of Medicine, School of Medicine, Jeju National University, 102 Jejudaehakno, Jeju 63243, Korea; \\ jikang0024@jejunu.ac.kr (J.-I.K.); loveis6776@hanmail.net (M.-K.K.); yskoh7@jejunu.ac.kr (Y.-S.K.); \\ jinwonh@jejunu.ac.kr (J.-W.H.); yonse2004@hanmail.net (S.-Y.K.); eunsyoo@jejunu.ac.kr (E.-S.Y.) \\ 2 Department of Marine Life Science, Jeju National University, 102 Jejudaehakno, Jeju 63243, Korea; \\ lee198186@hanmail.net (J.-H.L.); youjinj@jejunu.ac.kr (Y.-J.J.) \\ 3 Aqua Green Technology Co. Ltd., 209 Jeju Bio-Industry Center, 102 Jejudaehakno, Jeju 63243, Korea \\ 4 Seaweed Research Center, National Institute of Fisheries Science, 130 Tongilro, Mokpo 58746, Korea; \\ ekhwang@hotmail.com \\ 5 Jeju Research Center for Natural Medicine, Jeju National University, 102 Jejudaehakno, Jeju 63243, Korea \\ * Correspondence: pharmkhk@jejunu.ac.kr; Tel.: +82-64-754-3846; Fax: +82-64-702-2687
}

Academic Editor: Peer B. Jacobson

Received: 16 March 2017; Accepted: 2 May 2017; Published: 5 May 2017

\begin{abstract}
In this study, we investigated the effect and mechanism of Undariopsis peterseniana, an edible brown alga, on hair growth. The treatment of vibrissa follicles with $U$. peterseniana extract ex vivo for 21 days significantly increased the hair-fiber lengths. The $U$. peterseniana extract also significantly accelerated anagen initiation in vivo. Moreover, we found that $U$. peterseniana extract was able to open the KATP channel, which may contribute to increased hair growth. The $U$. peterseniana extract decreased $5 \alpha$-reductase activity and markedly increased the proliferation of dermal papilla cells, a central regulator of the hair cycle. The U. peterseniana extract increased the levels of cell cycle proteins, such as Cyclin D1, phospho(ser780)-pRB, Cyclin E, phospho-CDK2, and CDK2. The $U$. peterseniana extract also increased the phosphorylation of ERK and the levels of Wnt $/ \beta$-catenin signaling proteins such as glycogen synthase kinase-3 $\beta$ (GSK-3 $\beta$ ) and $\beta$-catenin. These results suggested that the $U$. peterseniana extract had the potential to influence hair growth by dermal papilla cells proliferation through the activation of the $\mathrm{Wnt} / \beta$-catenin and ERK pathways. We isolated a principal of the $U$. peterseniana extract, which was subsequently identified as apo-9'-fucoxanthinone, a trichogenic compound. The results suggested that U. peterseniana extract may have a pivotal role in the treatment of alopecia.
\end{abstract}

Keywords: Undariopsis peterseniana; hair growth; KATP channel; $5 \alpha$-reductase; dermal papilla cell; Wnt/ $\beta$-catenin; apo-9'-fucoxanthinone

\section{Introduction}

Hair loss (alopecia) is a distressing disorder and has several contributory factors, including the imbalance of hormones, stress, poor nutrition, and chemotherapy [1-3]. Two drugs, minoxidil $\left(\right.$ Rogain $^{\circledR}$ ) and finasteride (Propecia ${ }^{\circledR}$ ), have been approved by the Food and Drug Administration to alleviate hair loss [4,5]. Minoxidil, a KATP channel opener, was originally used to treat hypertension $[4,6]$, but has also been shown to cure alopecia [6]. Finasteride has been widely used to cure prostatic hypertrophy and androgenetic alopecia [5,6]. However, when it is used for the treatment of patients with alopecia, weaknesses arise, including transient action and infertility problems $[6,7]$. 
Therefore, there is a high demand for other substances that may be used for the treatment of alopecia.

The hair follicle is a small organ that undergoes structural changes depending on the hair cycle, such as in the growth (anagen), regression (catagen), and resting (telogen) phases [8]. Throughout the hair cycle, the growth of hair follicles (HF) is regulated by the interaction between adjacent hair follicle cells, including dermal papilla and stem cells (SC) [9]. In particular, dermal papilla cells, mesenchymal derived fibroblasts, operate as a central regulator in the hair cycle [10]. At the end of telogen phase, the signals from the dermal papilla are transmitted to SC and/or hair germ cells to initiate hair growth [10]. Studies on hair growth have shown that the proliferation of dermal papilla cells was accompanied by increase in the duration of the anagen phase [11]. Several signaling proteins, such as Wnt/ $\beta$-catenin and extracellular signal regulated kinases (ERK), were upregulated in dermal papilla cells after minoxidil treatment and led to the proliferation of dermal papilla cells [11,12]; this was accompanied by the alteration of cell cycle proteins, including cyclin E, cyclin dependent kinases 2 (CDK2), and p27Kip1 [13]. The Wnt/ $\beta$-catenin pathway is crucial in both hair growth and follicle development [14,15]. A study on the role of $\beta$-catenin, a component of the Wnt/ $\beta$-catenin pathway, observed hair loss in mice lacking $\beta$-catenin [15], which suggested that alteration of the Wnt/ $\beta$-catenin pathway might induce hair growth or alopecia. The ERK pathway has been shown to affect cellular functions including cell proliferation and apoptosis $[16,17]$. Several activators of hair-growth, such as the vascular endothelial growth factor, placental growth factor, and adenosine, have displayed ERK-mediated hair growth effects [18,19].

Undariopsis peterseniana, an edible brown alga with a rich source of nutrients such as amino acids and minerals, is found in abundance on the coast of Jeju Island, Korea. Several studies have focused on the cultivation of $U$. peterseniana $[20,21]$. The antioxidant activity of $U$. peterseniana has also been demonstrated by using the DPPH radical scavenging assay [22]. However, the effects of $U$. peterseniana on hair growth, and the underlying mechanisms of action, have not been investigated. This study investigated the in vitro, ex vivo, and in vivo effects and mechanism of U. peterseniana extract on hair growth.

\section{Results}

\subsection{Ex Vivo Effect of U. peterseniana Extract on the Hair-Fiber Length of Rat Vibrissa Follicles}

To test the effect of $U$. peterseniana extract on hair growth, we evaluated the change in hair-fiber length using organ cultures of rat vibrissa follicles [23]. Isolated rat vibrissa follicles were treated with $U$. peterseniana extract $(1,10$, and $100 \mu \mathrm{g} / \mathrm{mL})$ for 21 days and the hair-fiber length was measured on days $0,7,14$, and 21 after isolation. The hair-fiber lengths of the vibrissa follicles treated with $U$. peterseniana extract $(1 \mu \mathrm{g} / \mathrm{mL})$ significantly increased after 7 days; the increase continued for 21 days (Figure 1A,B). On day 21, U. peterseniana extract ( 1 and $10 \mu \mathrm{g} / \mathrm{mL}$ ) had increased the hair-fiber length by $206.5 \%$ and $165.6 \%$, respectively, compared with vehicle-treated control (Figure 1B). In particular, $1 \mu \mathrm{g} / \mathrm{mL} U$. peterseniana extract significantly increased the hair-fiber length compared with the positive control of $10 \mu \mathrm{M}$ minoxidil, whereas $100 \mu \mathrm{g} / \mathrm{mL} U$. peterseniana extract did not affect the hair-fiber length (Figure 1B). 


\section{(A)}
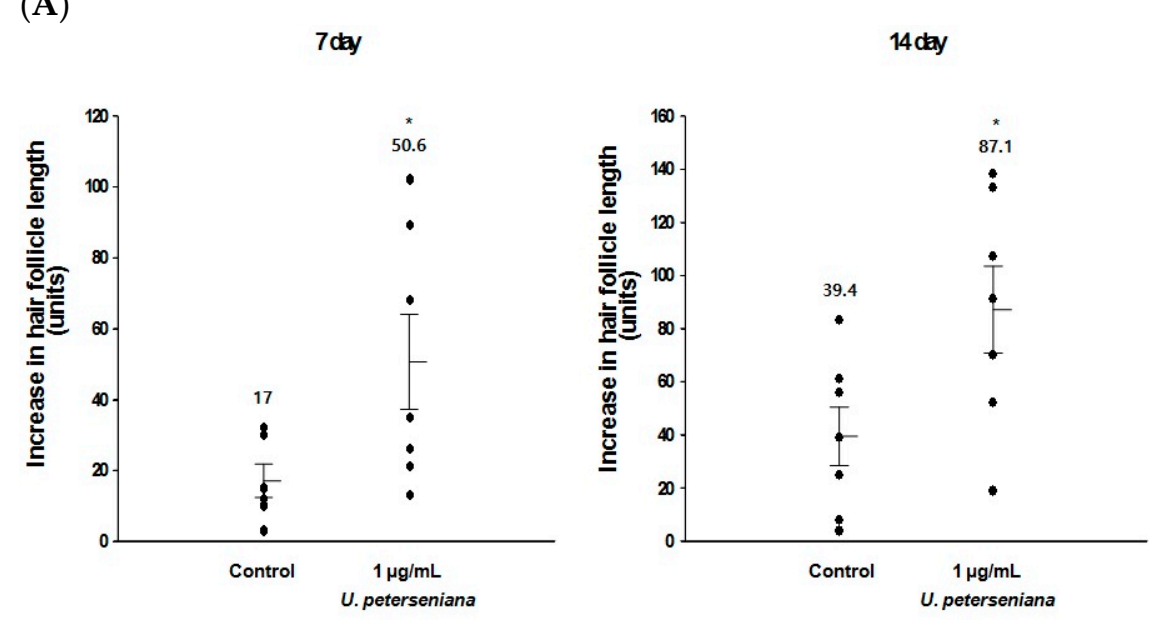

(B)

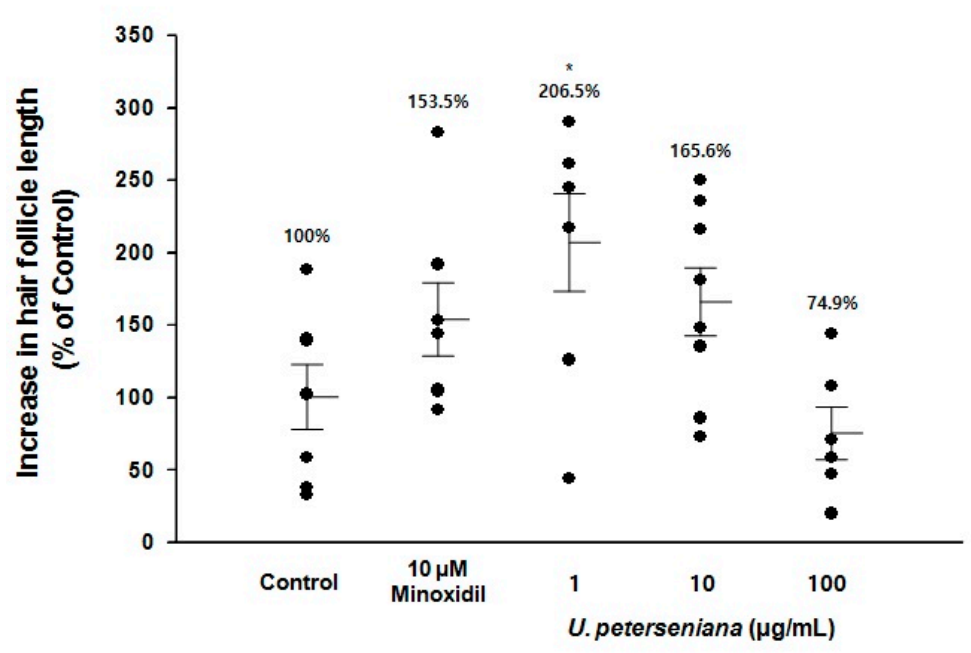

Figure 1. Undariopsis peterseniana extract increases hair growth in ex vivo organ culture. Rat vibrissa follicles were cultured with the indicated concentrations of $U$. peterseniana extract or minoxidil for 21 days. (A) The time course change of hair-fiber length was measured by DP controller software. Each dot indicates an independent follicle length. Horizontal lines showed mean \pm SE. ${ }^{*} p<0.05$ compared with the control; (B) The change in length of vibrissa follicles at 21 days was compared to the mean length of control follicles. The mean length of control follicles was set at $100 \%$ and each dot indicates an independent follicle length (\%). Horizontal lines showed the mean \pm SE. ${ }^{*} p<0.05$ compared with the control.

\subsection{Effect of U. peterseniana Extract on the Telegen to Anagen Progression in C57BL/6 Mouse}

In order to evaluate the in vivo effect on hair growth, C57BL/6 mice whose hair cycle was consistent with changes in skin color were used for in vivo experiments [8]. More specifically, it is known that skin color changes from pink to black when the hair cycle progress from telogen to anagen in previous studies [8]. U. peterseniana extract $(0.1,1$, and $10 \mu \mathrm{g} / \mathrm{mL})$ was topically applied to the skin of C57BL/6 mice from 1 day after shaving and the treatment was applied daily for 34 days. On the day $34, U$. peterseniana extract induced gray/black skin, but the vehicle-treated control was visibly less pigmented (Figure 2A). On day 34 after treatment with $U$. peterseniana extract, the quantification of anagen progression was analyzed using dotmatrix planimetry [24]. The $10 \mu \mathrm{g} / \mathrm{mL}$ $U$. peterseniana extract-treated mice showed larger gray/black skin area than vehicle-treated mice (Figure 2B). From day 12, the skin color of MINOXYL ${ }^{\mathrm{TM}}$ (5\% minoxidil)-treated mice changed to gray, and after 26 days, the hair was fully grown (Figure 2A). These results indicated that $U$. peterseniana extract significantly induced transition of the hair cycle from the telogen phase to the anagen phase in vivo. 
(A)

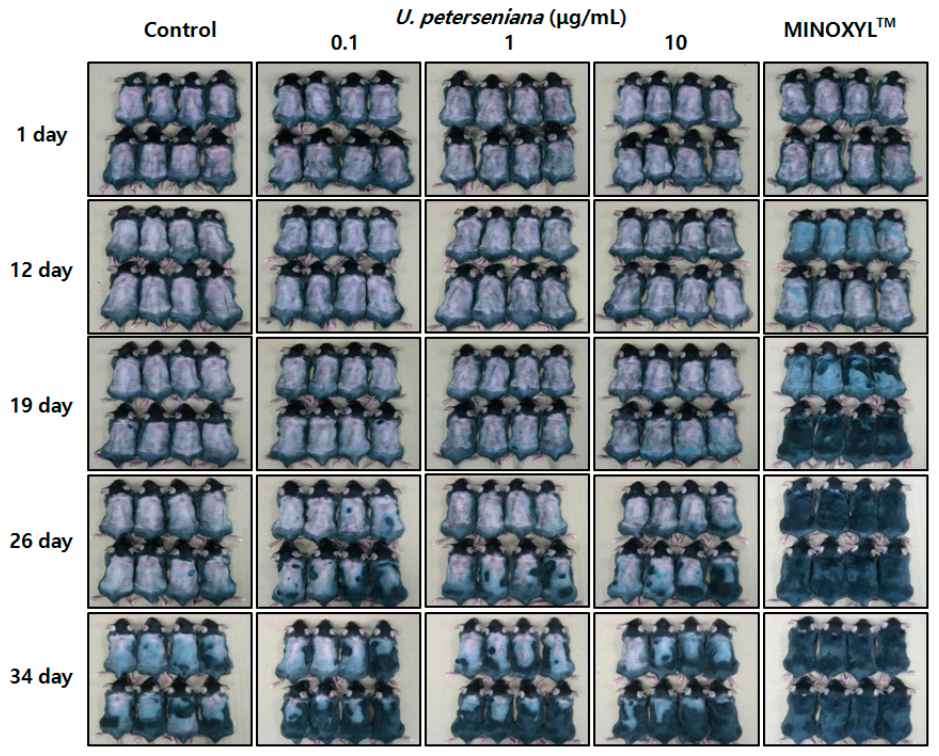

(B)

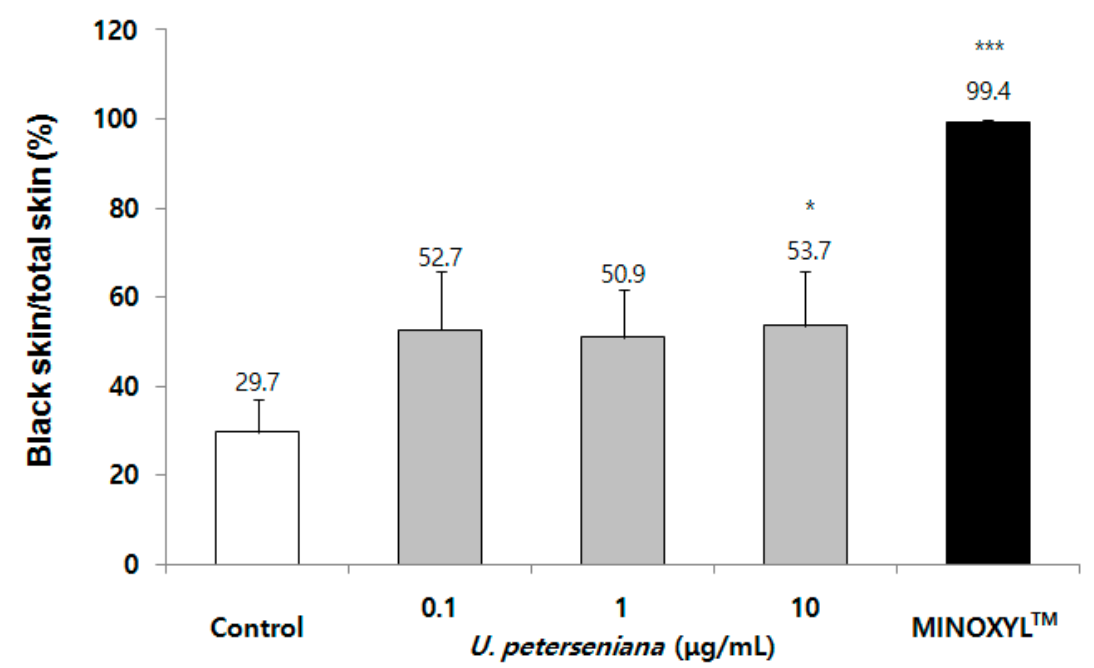

Figure 2. U. peterseniana extract accelerates the progression of anagen phase in vivo. $U$. peterseniana extract $(0.1,1$, and $10 \mu \mathrm{g} / \mathrm{mL})$ was topically treated to C57BL/6 mice dorsal skin for 34 days. (A) The change in skin color was observed after photographing at the indicated times after depilation; (B) Quantification of anagen induction by dotmatrix planimetry. On day 34, the area of interest in back skin was marked in transparency film. Acceleration to the anagen phase was expressed as a percentage of the area of the black skin compare to the total skin area. Data are presented as the mean $\pm \mathrm{SE}(n=8) .{ }^{*} p<0.05,{ }^{* * *} p<0.001$ compared with the control.

\subsection{Effect of U. peterseniana Extract on the $5 \alpha$-Reductase Activity}

$5 \alpha$-Reductase has been reported to be highly expressed in HF of androgenetic alopecia patients [25]. Clinical trials have revealed that treatment with finasteride, a type II $5 \alpha$-Reductase inhibitor, led to the prevention of hair loss [5]. To evaluate whether $U$. peterseniana extract could inhibit $5 \alpha$-reductase activity, we used a crude $5 \alpha$-reductase from rat prostate. The addition of $U$. peterseniana extract $(0.1,1,10$, and $100 \mu \mathrm{g} / \mathrm{mL})$ to the reaction mixture inhibited $5 \alpha$-reductase activity by $25.8 \%, 30.8 \%(p<0.05), 41.9 \%(p<0.01)$, and $22.5 \%$, respectively (Figure 3$)$. Finatseride $(2 \mathrm{nM})$ also significantly inhibited the $5 \alpha$-reductase activity by $88.3 \%(p<0.001)$ (Figure 3$)$. These results suggested that $U$. peterseniana extract may have the potential to treat androgenetic alopecia; however, the $5 \alpha$-reductase activity of $U$. peterseniana extract was lower than that of finasteride. 


\section{$5 \alpha-$ reductase assay}

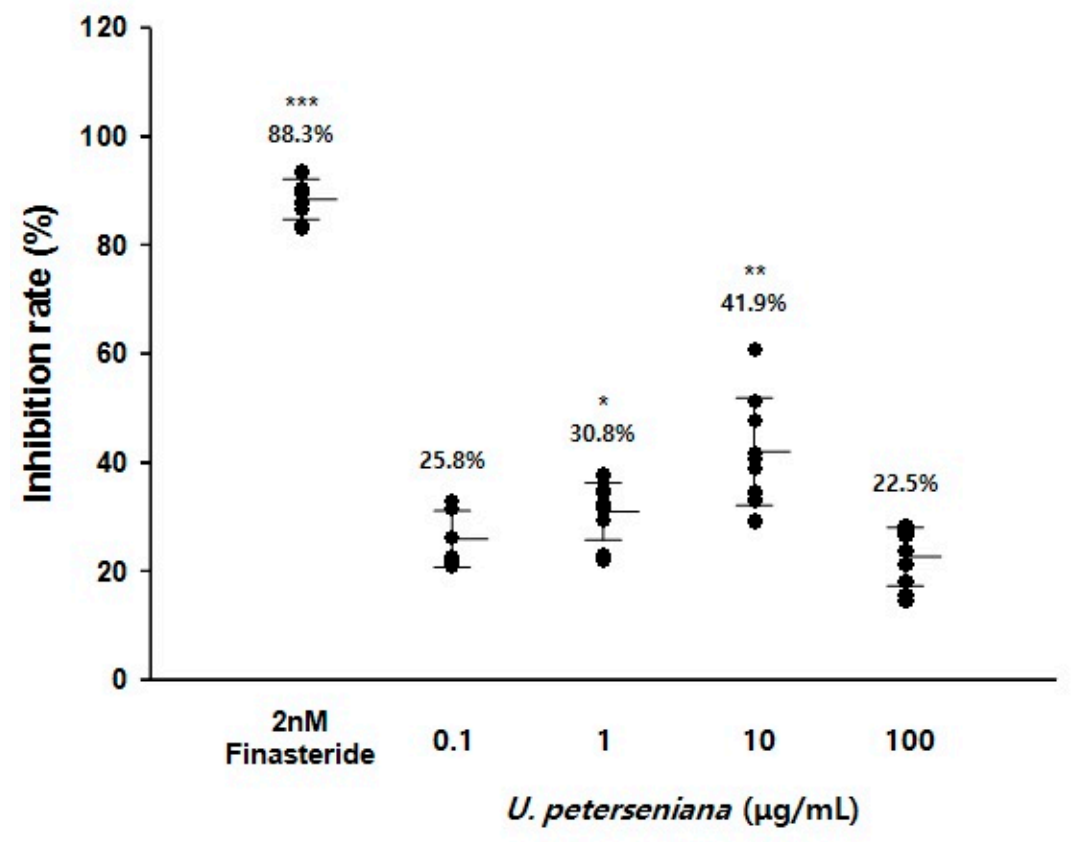

Figure 3. U. peterseniana extract inhibits $5 \alpha$-reductase activity. $5 \alpha$-Reductase activity was measured by liquid scintillation counting using $\left[1,2,6,7-{ }^{3} \mathrm{H}\right]$ testosterone. The reaction mixtures were incubated with the indicated concentrations of $U$. peterseniana extract or finasteride in the presence of crude extract of rat prostate. The conversion rate of testosterone (T) to dihydrotestosterone (DHT) was calculated by the equation: $[\mathrm{DHT} /(\mathrm{T}+\mathrm{DHT})] \times 100$. The inhibition rate of $5 \alpha$-reductase activity $(\%)$ was estimated as a percentage of the reduction in conversion rate compared with the control. The inhibition rate of the control group was considered $0 \%$ (not shown). Horizontal lines show the mean \pm SD. Finasteride was used as reference material to evaluate the inhibition of $5 \alpha$-reductase activity.

\subsection{Effect of U. peterseniana Extract on the Proliferation of NIH3T3 Fibroblasts via KaTP Channel Opening}

Minoxidil, a KATP channel opener, has a mitogenic effect on NIH3T3 fibroblasts [26]. The 3-[4,5-dimethylthiazol-2-yl]-2,5-diphenyltetrazolium bromide (MTT) assay revealed that minoxidil-induced proliferation of NIH3T3 fibroblasts was inhibited by KATP channel blockers [26].

To address whether $U$. peterseniana extract acted as an opener of the KATP channel, we investigated the proliferation of NIH3T3 fibroblasts using tetraethylammonium (TEA), a KATP channel blocker, by an MTT assay. U. peterseniana extract ( 1 and $10 \mu \mathrm{g} / \mathrm{mL})$ significantly increased the proliferation of NIH3T3 fibroblasts compared with the vehicle-treated control $(107.3 \%$ and $117.7 \%$, respectively) (Figure 4). TEA ( $2 \mathrm{mM}$ ) completely inhibited the increase in the proliferation of NIH3T3 fibroblasts caused by $U$. peterseniana extract. Minoxidil increased the proliferation of NIH3T3 fibroblasts by $147.8 \%$ at a concentration of $75 \mu \mathrm{M}$; this increase was also completely inhibited by $2 \mathrm{mM}$ TEA (Figure 4). These data indicated that the opening of the KatP channel led to an increase in the proliferation of NIH3T3 fibroblasts. The results indicated that $U$. peterseniana extract could act as a KATP channel opener, which could be a contributory factor in the effect on hair growth. 


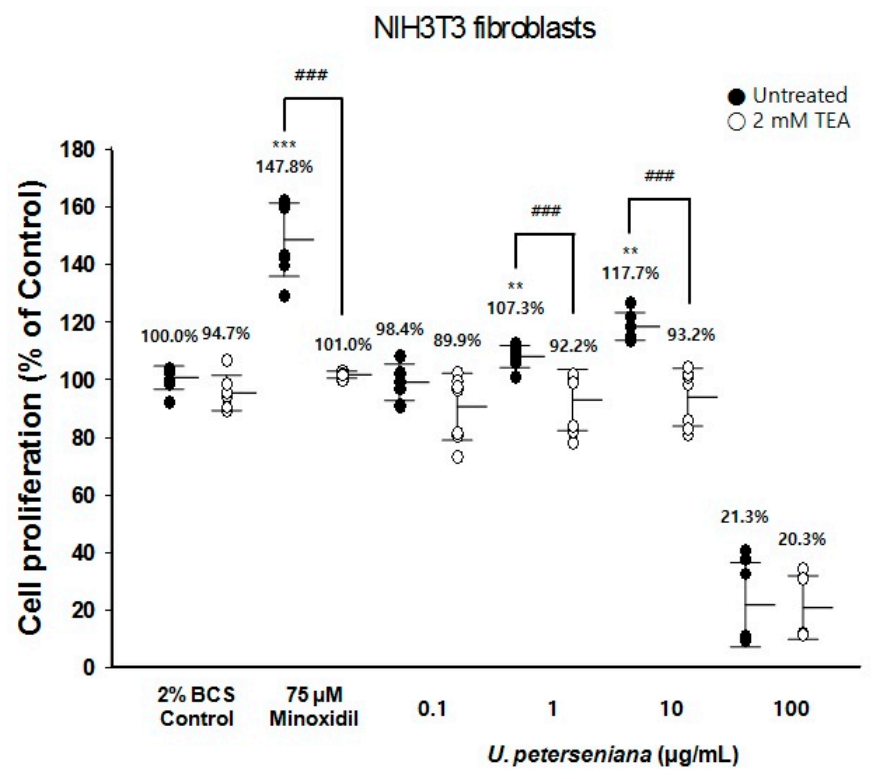

Figure 4. Effect of $U$. peterseniana extract on the proliferation of NIH3T3 fibroblast via the opening of KATP channel. The proliferation of NIH3T3 fibroblasts by the opening of KATP channel was measured by MTT assay and tetraethylammonium (TEA) was used as a KATP channel blocker. NIH3T3 fibroblasts were pretreated with or without $2 \mathrm{mM}$ TEA, and treated with various concentrations of $U$. peterseniana extract for 4 days. The proliferation of NIH3T3 fibroblasts was evaluated compared with the $2 \%$ BCS control. Each dot indicates an independent experiment and horizontal lines show the mean \pm SD. Indicated concentration of minoxidil and TEA were used as reference materials to evaluate cell proliferation by KATP channel. ${ }^{* *} p<0.01,{ }^{* *} p<0.001$ compared with the control; ${ }^{* \#} p<$ 0.001 compared with the TEA-treated group.

\subsection{Effects of U. peterseniana Extract on the Proliferation of Dermal Papilla Cells}

To test the effect of $U$. peterseniana extract on hair follicular cells, the proliferation of dermal papilla cells was measured by the MTT assay after incubation with $U$. peterseniana extract $(0.1,1$, and $10 \mu \mathrm{g} / \mathrm{mL})$ for $96 \mathrm{~h}$. U. peterseniana extract $(1$ and $10 \mu \mathrm{g} / \mathrm{mL})$ significantly increased the proliferation of dermal papilla cells by $112.4 \%(p<0.01)$ and $146.2 \%(p<0.001)$, respectively (Figure 5A). The positive control, minoxidil $(10 \mu \mathrm{M})$ significantly increased the proliferation of dermal papilla cells by $114.5 \%(p<0.05)$ compared with the control (Figure 5A). These results suggested that $U$. peterseniana extract could exert a promotional effect on hair-growth via the proliferation of dermal papilla cells.

\subsection{Effects of U. peterseniana Extract on the Levels of Cell Cycle Proteins, Wnt/ $\beta$-Catenin Signaling, and Erk1/2 Signaling in Dermal Papilla Cells}

The progression of the cell cycle is required for cell proliferation and is driven by cell cycle-related proteins (cyclin/CDKs complexes and CDK inhibitors) [27]. To investigate whether $U$. peterseniana extract increased the proliferation of dermal papilla cells by the regulation of cell cycle-related proteins, we examined changes in the levels of Cyclin D1, phospho(ser780)-pRB, Cyclin E, phospho-CDK2, and CDK2 after treatment with $U$. peterseniana extract $(1,10$, and $100 \mu \mathrm{g} / \mathrm{mL})$ for $24 \mathrm{~h}$ in dermal papilla cells. $U$. peterseniana extract increased the levels of Cyclin D1, phospho(ser780)-pRB, Cyclin E, phospho-CDK2, and CDK2 (Figure 5B).

The Wnt/ $\beta$-catenin pathway is crucial for the proliferation of dermal papilla cells and hair growth [28]. Therefore, we addressed whether $U$. peterseniana extract could activate the $\mathrm{Wnt} / \beta$-catenin pathway. We examined the changes in the levels of phosphorylation of $\beta$-catenin at ser552, 675, phosphorylation of GSK-3 $\beta$ at ser9, and GSK-3 $\beta$ following the treatment of $U$. peterseniana extract for $24 \mathrm{~h}$. U. peterseniana extract increased the levels of phosphorylation of $\beta$-catenin at ser552, 675, phosphorylation of GSK-3 $\beta$ at ser9, and GSK-3 $\beta$ in dermal papilla cells (Figure 5C). The treatment with minoxidil $(10 \mu \mathrm{M})$ resulted in an increase in the levels of 
phosphorylation of $\beta$-catenin at ser552, 675, $\beta$-catenin, and phosphorylation of GSK-3 $\beta$ at ser9 compared with the vehicle-treated control (Figure 5C). The data showed that minoxidil and $U$. peterseniana extract increased the level of $\beta$-catenin in the nucleus through the regulation of GSK-3 $\beta$ [11]. The results indicated that $U$. peterseniana extract could increase the proliferation of dermal papilla cells via the activation of the Wnt/ $\beta$-catenin pathway.

The ERK pathway is also important in cell proliferation [16]; the inhibition of ERK has been shown to result in a decrease in cell proliferation [29]. We therefore examined the changes in the level of phospho-ERK1/2 after the treatment of $U$. peterseniana extract. The increase of phospho-Erk1/2 level was observed in cells treated with U. peterseniana extract (Figure 5D), which indicated that the activation of ERK pathway by $U$. peterseniana extract contributed to the proliferation of dermal papilla cells.

(A)

$$
\text { Dermal papilla cells }
$$

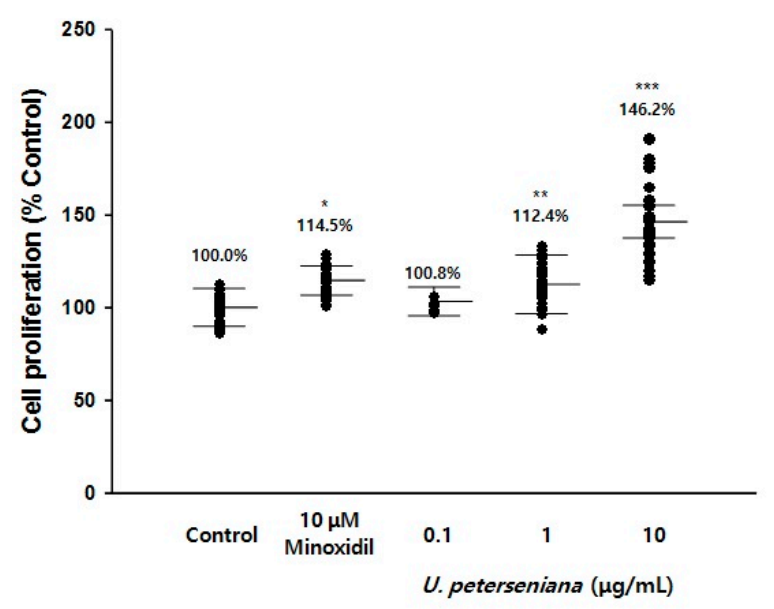

(B)
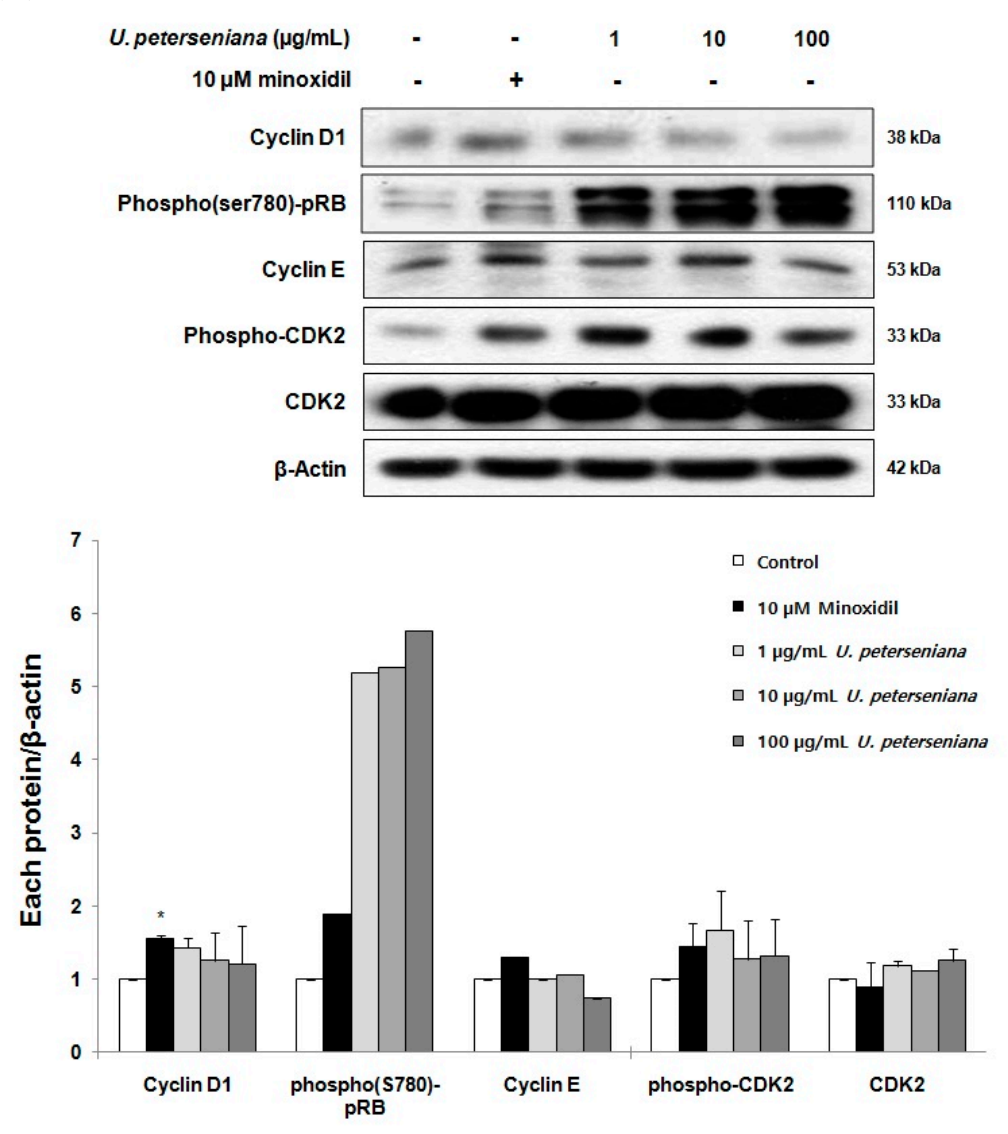
(C)
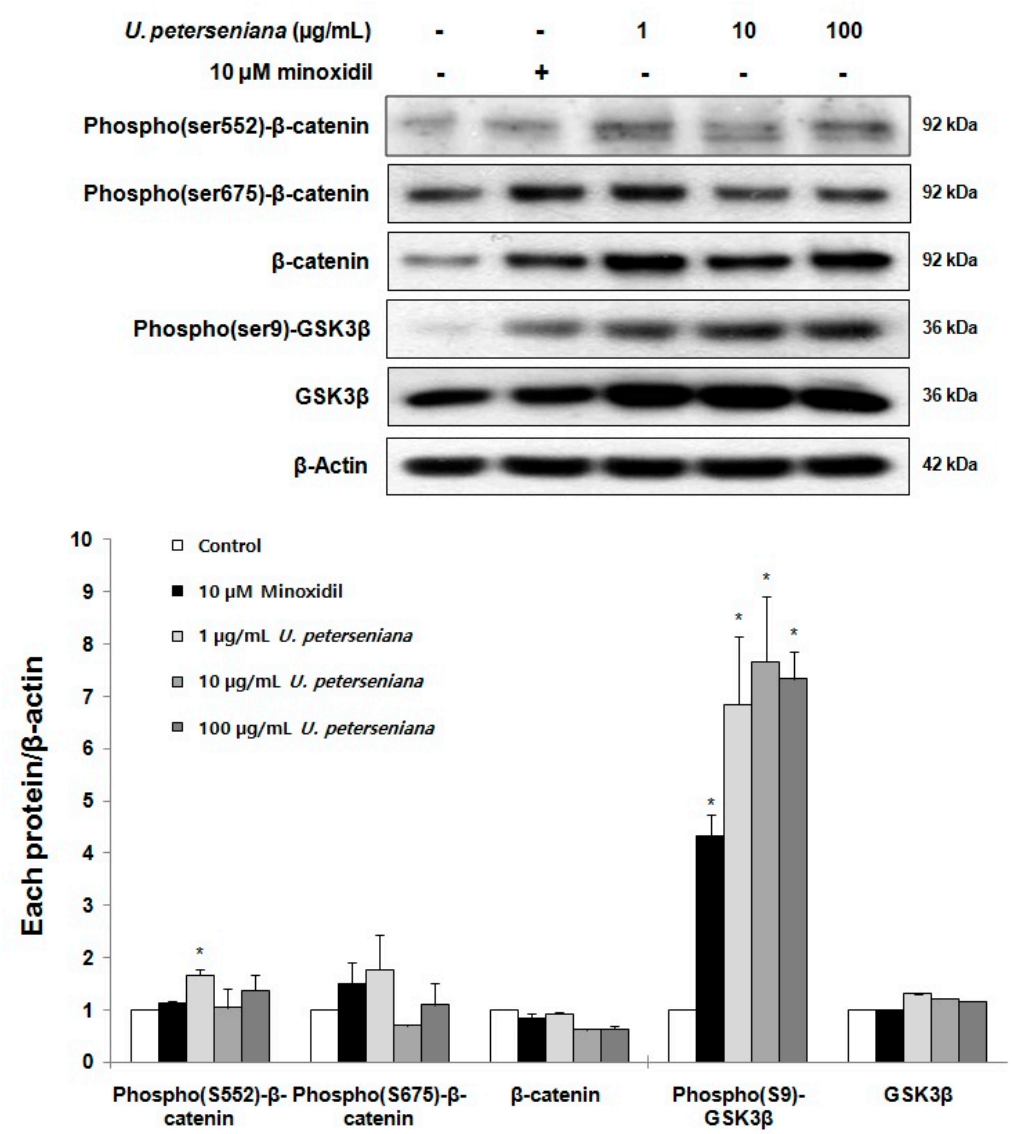

(D)
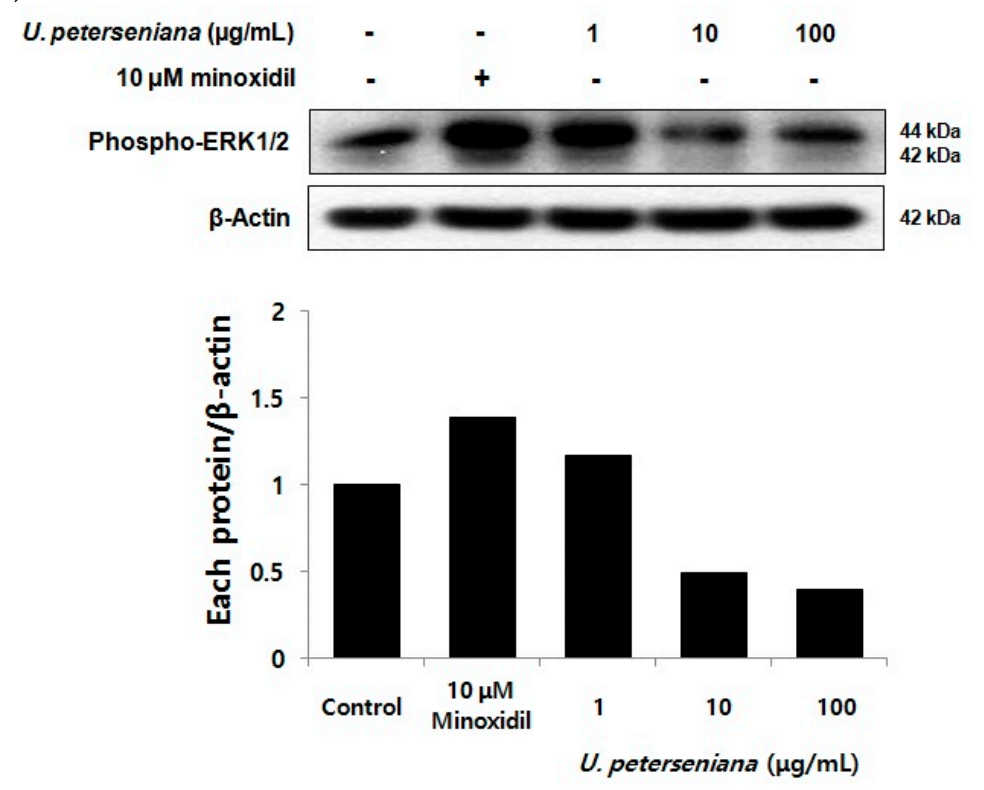

Figure 5. U. peterseniana extract increases the proliferation of dermal papilla cells as well as the levels of different proteins (cell cycle proteins, Wnt/ $\beta$-catenin, and phospho-ERK) in dermal papilla cells. (A) The dermal papilla cells were stimulated with $U$. peterseniana extract and minoxidil, indicated concentrations for $96 \mathrm{~h}$. The MTT assay was used to assess the proliferation of dermal papilla cells. Each dot indicates an independent experiment and horizontal lines showed the mean \pm SD. ${ }^{*} p<0.05,{ }^{* *} p$ $<0.01{ }^{* *} p<0.001$ compared with the control; (B-D) The dermal papilla cells $\left(1.0 \times 10^{6}\right.$ cells $)$ were stimulated $U$. peterseniana extract and minoxidil, indicated concentrations for $24 \mathrm{~h}$. The whole cell lysate from dermal papilla cells were subjected to immunoblotting with indicated antibodies. ${ }^{*} p<0.05$ compared with the control. 


\section{Discussion}

In the present study, we demonstrated that $U$. peterseniana extract promoted the growth of hair by facilitating both the elongation of hair-fiber length and initiation of anagen. Moreover, we observed that in addition to the inhibition of $5 \alpha$-reductase activity and KATP channel opening, $U$. peterseniana extract could induce the proliferation of dermal papilla cells via the activation of Wnt/ $\beta$-catenin and ERK pathways.

A previous study determined that $5 \alpha$-reductase converted T to DHT, a potent form of $\mathrm{T}$, which induced the progression of alopecia [5]. Inhibition of $5 \alpha$-reductase activity in alopecia patients decreased the level of DHT in the scalp, which led to a decrease in the progression of alopecia [30]. Finasteride, the type II $5 \alpha$-reductase inhibitor, was shown to cure androgenetic alopecia by a reduction of DHT level [5]. In this study, $U$. peterseniana extract displayed an inhibitory effect on $5 \alpha$-reductase activity, which suggested that $U$. peterseniana extract has the potential to prevent androgenetic alopecia by the inhibition of $5 \alpha$-reductase activity. Apo-9'-fucoxanthinone, a principal compound of brown algae including $U$. peterseniana, has also been shown to inhibit $5 \alpha$-reductase activity (Figure 6) [31,32].

KATP channels are expressed in HF and the channel opening has been linked to cell proliferation and hair growth [26,33]. In this study, the proliferation of NIH3T3 fibroblasts in response to $U$. peterseniana extract was completely mitigated by TEA, a KATP channel blocker. The role of KATP channel opening in response to minoxidil was supported by the finding that treatment with TEA blocked the minoxidil-induced proliferation of NIH3T3 fibroblasts [26]. These results indicated that $U$. peterseniana extract had the potential to increase cell proliferation by opening the KATP channels. Apo-9'-fucoxanthinone was found to be a principal of both the U. peterseniana extract and Sargassum muticum extract [31,32]. Nevertheless, on the proliferation of NIH3T3 fibroblast via the opening of KATP channel, U. peterseniana extract $(1$ and $10 \mu \mathrm{g} / \mathrm{mL})$ significantly increased the proliferation of NIH3T3 fibroblasts, whereas apo-9'-fucoxanthinone could not change that (data not shown). To explain the discrepancy of effects between $U$. peterseniana extract and apo-9'-fucoxanthinone, we need to find the other components from U. peterseniana extract.

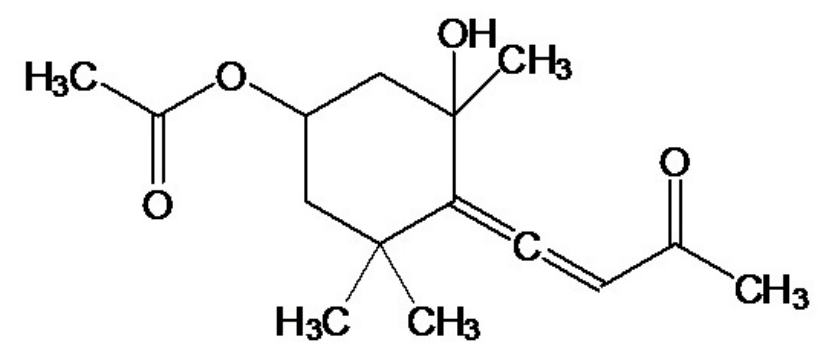

\section{Apo-9'-fucoxanthinone}

Figure 6. Structure of apo-9'-fucoxanthinone isolated from U. peterseniana.

We investigated the effect of $U$. peterseniana extract on the increase of hair-fiber length as an ex vivo experiment. The culture of HF has many advantages: at least two distinct aspects such as the measure of hair-fiber length and maintenance of normal architecture [23,34]. A previous study showed that minoxidil increased not only the length of hair-fiber in the organ culture of mouse HF, but also thymidine incorporation [34]. Likewise, our findings revealed that the hair-fiber lengths of follicles stimulated with $U$. peterseniana extract $(1 \mu \mathrm{g} / \mathrm{mL})$ were significantly longer than those of follicles treated with minoxidil, which has been used in hair research models both ex vivo and in vivo as a positive control. It has previously been suggested that the progression of the hair cycle was confirmed by a change in skin color from pink to gray/black $[8,24]$. Treatment with $U$. peterseniana extract also boosted anagen initiation in C57BL/6 mice. The results indicated that $U$. peterseniana extract had the potential to promote hair growth by the partial regulation of distinct effects that resulted from the KaTP channel opening and the inhibition of $5 \alpha$-reductase activity. 
Except for the results of the length of hair-fiber in culture of HF, the other results showed that the $U$. peterseniana extract $(10 \mu \mathrm{g} / \mathrm{mL})$ exhibited significant effects. According to our previous research [32], a possible explanation for this was as follows: in the experiment on the culture of HF, the culture medium containing $U$. peterseniana extract was changed every 3 days, and this practice was continued for 21 days. Therefore, the effective concentration was lower than expected, because $U$. peterseniana extract and its metabolites were concentrated in HF.

The size and number of dermal papilla cells located at the base of HF are known to be related to hair cycle and hair growth [35]. During the hair cycle, dermal papilla cells are known to interact with hair follicle SC and hair germ cells and to mediate the transition from telogen to anagen in the hair cycle by the regulation of the signaling pathway, including fibroblast growth factors and Wnt/ $\beta$-catenin proteins, which led to an early onset of anagen phase [10].

Cell cycle control is important for cell proliferation [27]. The role of cell cycle promoting proteins including phospho-pRB and cyclins is to induce the cell cycle progression from G0/1 to $S$ phase; Cell cycle inhibitory proteins (CDK inhibitors) prevent this process [27]. In the present study, $U$. peterseniana extract upregulated the level of cyclin D1, phospho-pRB, cyclin E, phospho-CDK2, and CDK2, followed by the proliferation of dermal papilla cells. We previously demonstrated that Ishige sinicola, a brown alga, or minoxidil, could increase the levels of cyclin E and CDK2, but decreased the level of the p27kip1, a CDK inhibitor in dermal papilla cells [36]. This was further supported by the observation that glibenclamide, a KАтP channel blocker, inhibited cell proliferation, which was accompanied by an increase in cell cycle arrest and the p27kip1 level [37]. These results suggested that $U$. peterseniana extract increased the proliferation of dermal papilla cells through the progression of the cell cycle by the alteration of the level of cell cycle proteins. On the other hand, on the proliferation of dermal papilla cells, the efficacy of $U$. peterseniana extract $(146.2 \%)$ was higher than that of apo-9'-fucoxanthinone (121.7\%), an active component of the $U$. peterseniana extract. In further study, we need to isolate other components in order to address the discrepancy of effects between $U$. peterseniana extract and apo-9'-fucoxanthinone.

The Wnt/ $\beta$-catenin pathway is one of the master regulator of cell growth in several cell types, including hair follicle SC and pancreatic beta cells $[28,38]$, and is inhibited by GSK-3 $\beta[39,40]$. Previous findings suggested that the inactivation of GSK-3 $\beta$ by LiCl, an inhibitor of GSK-3 $\beta$, led to a decrease in the ubiquitination of $\beta$-catenin, which resulted in the phosphorylation and translocation of $\beta$-catenin into the nucleus [40]. The increased level of $\beta$-catenin in the nucleus activates target genes such as cyclin D1, thereby allowing cell proliferation [41]. In several studies, natural products have been reported to increase hair growth by Wnt/ $\beta$-catenin activation $[42,43]$. Our study revealed that $U$. peterseniana extract enhanced the levels of phosphorylation of GSK-3 $\beta$ at ser9 and phosphorylation of $\beta$-catenin at ser552, 675 in dermal papilla cells. Apo-9'-fucoxanthinone, an active compound of $U$. peterseniana, was reported to increase the levels of phosphorylation of GSK-3 $\beta$ at ser9 and phosphorylation of $\beta$-catenin at ser552 [32]. The Wnt/ $\beta$-catenin activation by $U$. peterseniana extract and apo-9'-fucoxanthinone is involved in the proliferation of dermal papilla cells. However, our study did not address what type of kinase regulated the phosphorylation of $\mathrm{Wnt} / \beta$-catenin proteins, although the activation of $\mathrm{Wnt} / \beta$-catenin proteins are known to be regulated by protein kinase A and protein kinase B [40,44,45]. Further studies using specific inhibitors are necessary to reveal the detailed mechanism.

The activation of the ERK pathway is important for the proliferation of various cell types including dermal papilla cells $[16,46]$. In this study, we showed that $U$. peterseniana extract increased the phosphorylation of ERK in dermal papilla cells. Endothelin, a mitogen of airway smooth muscle, increased cell proliferation, which was inhibited by PD98059, an ERK inhibitor [29]. Our results indicated that $U$. peterseniana extract has the potential to increase the proliferation of dermal papilla cells through the regulation of ERK phosphorylation. In addition, a direct association between the upregulation of cyclin D1 and the phosphorylation of ERK has been reported [47]. As mentioned above, our findings showed that $U$. peterseniana extract increased the levels of cyclin D1, $\beta$-catenin, an upstream regulator of cyclin D1, and the phosphorylation of ERK in dermal papilla cells, which 
suggested that $U$. peterseniana extract increased the proliferation of dermal papilla cells through the regulation of the levels of cell cycle proteins, Wnt/ $\beta$-catenin proteins, and the phosphorylation of ERK.

In the study, we identified the hair growth-promoting effects of $U$. peterseniana via the proliferation of dermal papilla cells, opening of KATP channels, and the inhibition of $5 \alpha$-reductase activity. Furthermore, U. peterseniana extract could induce the proliferation of dermal papilla cells via the increase of cell cycle proteins and the activation of $\mathrm{Wnt} / \beta$-catenin and ERK pathways. We also identified apo-9'-fucoxanthinone as an active component of $U$. peterseniana extract. Collectively, these results suggested that $U$. peterseniana extract may be used for the development of a new therapeutic substance for the treatment of alopecia.

\section{Materials and Methods}

\subsection{Reagents}

Earle's balanced salt solution (EBSS), dimethyl sulfoxide (DMSO), dithiothreitol (DTT), hydrocortisone, insulin, minoxidil, phosphate-buffered saline (PBS), phenylmethylsulfonylfluoride (PMSF), tetraethylammonium (TEA) and MTT were purchased from Sigma-Aldrich (St. Louis, MO, USA). Fetal bovine serum (FBS), bovine calf serum (BCS), Williams medium E, L-glutamine and penicillin/streptomycin solution (Pen Strep) were purchased from Gibco (Gibco Life Technologies, Grand Island, NY, USA). Dulbecco's modification of Eagle's medium was purchase from Hyclone (Logan, UT, USA). Aprotinin and leupeptin were purchased from Calbiochem (San Diego, CA, USA).

\subsection{Preparation of Undariopsis peterseniana Extract}

Undariopsis peterseniana was collected along the coast of Jeju Island, Korea, between April and July 2010 and identified by Dr Eun-Kyoung Hwang. A voucher specimen (SRI-P00017) was deposited at the herbarium of the Seaweed Research Center, National Fisheries Research and Development Institute. The sample was washed with distilled water, and stored at $-20{ }^{\circ} \mathrm{C}$. The frozen sample was finely homogenized with a grinder. The $15 \mathrm{~kg}$ of $U$. peterseniana was extracted with the three sample volumes of $70 \%$ ethanol and then concentrated using a vacuum evaporator. The resulting residue $(600 \mathrm{~g})$ was stored at $-20^{\circ} \mathrm{C}$ for use in subsequent experiments. U. peterseniana extract was dissolved in DMSO at a concentration of $50 \mathrm{mg} / \mathrm{mL}$ and stored at $-20{ }^{\circ} \mathrm{C}$ until use. From the $U$. peterseniana extract, we isolated apo-9'-fucoxanthinone by a centrifugal partition chromatography (CPC) system and preparative thin layer chromatography. The purified apo-9'-fucoxanthinone was identified by a comparison of the ${ }^{1} \mathrm{H}$ - and ${ }^{13} \mathrm{C}-\mathrm{NMR}$ data with those reported in the literature [31].

\subsection{Animals}

Three-week-old male Wistar rats, six-week-old female C57BL/6 mice, and seven-week-old male Sprague-Dawley (SD) rats were purchased from Orient Bio (Seongnam, Gyeonggi, Korea) and provided with a standard laboratory diet and water ad libitum. All animals were cared for by using protocols (20100031) approved by the Institutional Animal Care and Use Committee (IACUC) of Jeju National University.

\subsection{Isolation and Culture of Rat Vibrissa Follicles}

The isolation of rat vibrissa follicles was performed using the method of Philpott and Kealey [23]. Male Wistar rats (23 day old) were sacrificed under carbon dioxide $\left(\mathrm{CO}_{2}\right)$, and the mystacial pads were removed and placed in P/E buffer (1:1 mixture of PBS and EBSS that contained 1\% Pen Strep). Anagen vibrissa follicles were carefully isolated from mystacial pads using sterile dissecting forceps and blade while being observed under a stereomicroscope (Olympus, Tokyo, Japan). The isolated follicles were cultured in Williams medium E (Gibco Life Technologies, Grand Island, NY, USA) supplemented with $2 \mathrm{mM}$ L-glutamine (Gibco Inc., NY, USA), $50 \mathrm{nM}$ hydrocortisone, 10 $\mu \mathrm{g} / \mathrm{mL}$ insulin and $1 \%$ Pen Strep at $37{ }^{\circ} \mathrm{C}$ in an $5 \% \mathrm{CO}_{2} / 95 \%$ air. Minoxidil was dissolved in 0.12 
$\mathrm{mM} \mathrm{HCl}$ at a concentration of $5 \mathrm{mM}$ and used as the positive control [33]. The culture medium containing the $U$. peterseniana extract $(1,10$, and $100 \mu \mathrm{g} / \mathrm{mL})$ or $10 \mu \mathrm{M}$ minoxidil was changed every 3 days. The lengths of the HF were measured using DP controller software ver. 1.1.1.65 (Olympus, Tokyo, Japan).

\subsection{Hair Growth Activity In Vivo}

The anagen phase of hair cycle was induced by removing hair on the back skin of C57BL/6 mice, as described previously [8]. For anagen induction, the back skin of female C57BL/6 mice (P49) was shaved by animal clipper. U. peterseniana $(0.2 \mathrm{~mL})$ extract treatment began at P50, with daily administration for 34 days. Mice were photographed at 1, 12, 19, 26, and 34 days while observing changes in skin color on the back skin of the mice. Quantitative results were obtained using dotmatrix planimetry [24].

\subsection{Assay for Prostatic $5 \alpha$-Reductase Activity}

To prepare rat prostates, 8 -week-old male SD rats were sacrificed with $\mathrm{CO}_{2}$. The prostates were separated from surrounding capsules, washed twice with PBS, and stored at $-80{ }^{\circ} \mathrm{C}$. The weight of frozen prostate was measured. The five tissue volume of homogenase buffer $(20 \mathrm{mM}$ potassium phosphate buffer (pH 6.6), $0.32 \mathrm{M}$ sucrose, $25 \mu \mathrm{g} / \mathrm{mL}$ leupeptin, $25 \mu \mathrm{g} / \mathrm{mL}$ aprotinin, $1 \mathrm{mM}$ DTT, and $0.2 \mathrm{mM}$ PMSF) was added to prostate and homogenized with a taco ${ }^{\mathrm{TM}}$ Prep Bead Beater (GeneReach Corp., Taichung, Taiwan). The homogenates were centrifuged at 100,000× $g$ for $60 \mathrm{~min}$. The obtained pellets were suspended in homogenase buffer and stored at $-80{ }^{\circ} \mathrm{C}$ until use. $5 \alpha$-Reductase activities were analyzed by the measurement of the radioactivity using a liquid scintillation counter (LSC, Packard Bioscience, Meriden, CT, USA) as follows [48]. The $5 \alpha$-reductase reaction was initiated by the adding $250 \mu \mathrm{g}$ of prostatic enzyme fraction and $U$. peterseniana extract $(0.1,1,10$, and $100 \mu \mathrm{g} / \mathrm{mL}$ ) in reaction buffer (buffer A). The buffer A contained $40 \mathrm{mM}$ potassium phosphate buffer ( $\mathrm{pH}$ 6.6), $2 \mathrm{mM} \mathrm{NADPH}$, and $120 \mathrm{nCi}\left(1,2,6,7-{ }^{3} \mathrm{H}\right) \mathrm{T}$ and protease inhibitor cocktail. Three independent reactions were examined and finasteride was used as a positive control to confirm the inhibition of type II $5 \alpha$-reductase activity. The enzyme reaction was carried out at $37^{\circ} \mathrm{C}$ for $1 \mathrm{~h}$, and ethyl acetate (EtOAc) was added to stop the reaction. After the reaction, the sample was centrifuged at $1000 \times g$ for $5 \mathrm{~min}$, and the supernatant was transferred to a new tube. After drying on a heating plate, $50 \mu \mathrm{L}$ of EtOAc containing T $(500 \mu \mathrm{g} / \mathrm{mL})$ and DHT $(500 \mu \mathrm{g} / \mathrm{mL})$ was added to dissolve the residues. The sample was applied to a silica gel 60 F254 TLC plate and developed with a developing solvent (1:1 mixture of EtOAc:cyclohexane). After drying at $25^{\circ} \mathrm{C}$, the TLC spot of T was observed under UV light $(254 \mathrm{~nm})$. The TLC spot of DHT was visualized by soaking in $10 \%$ $\mathrm{H}_{2} \mathrm{SO}_{4}$ solution and heating with an alcohol lamp. The spot portion of $\mathrm{T}$ and DHT were clipped off and then dissolved in the ULTIMA GOLD ${ }^{\mathrm{TM}}$ Cocktail $(5 \mathrm{~mL})$. The activity of $5 \alpha$-reductase measured by LSC was expressed as a ratio calculated by the equation: $[\mathrm{DHT} /(\mathrm{T}+\mathrm{DHT})] \times 100$.

\subsection{Cell Culture}

Rat vibrissa immortalized dermal papilla cell line [49] was donated by the Skin Research Institute, Amore Pacific Corporation R\&D Center, South Korea. The mouse embryonic NIH3T3 fibroblasts were purchased from ATCC (Rockville, MD, USA). Dermal papilla cells were cultured in DMEM (Hyclone Inc., Logan, UT, USA) supplemented with 10\% heat-inactivated fetal bovine serum (FBS) (Gibco-BRL Inc., Long Island, NY, USA) and $1 \%$ Pen Strep at $37^{\circ} \mathrm{C}$ in a $5 \% \mathrm{CO}_{2} / 95 \%$ air. NIH3T3 fibroblasts were cultured in ATCC-formulated DMEM supplemented with $10 \%$ heat-inactivated bovine calf serum (BCS and $1 \%$ Pen Strep at $37^{\circ} \mathrm{C}$ in a $5 \% \mathrm{CO}_{2} / 95 \%$ air.

\subsection{Proliferation Assay of NIH3T3 Fibroblasts}

The MTT assay was used to determine the cell proliferation as described previously [50]. NIH3T3 fibroblasts were seeded at 2000 cells per well in 96-well plate in DMEM supplemented with $2 \%$ BCS. The cell were incubated for $24 \mathrm{~h}$ to allow attachment, $U$. peterseniana extract $(0.1,1,10$, 
and $100 \mu \mathrm{g} / \mathrm{mL})$ and minoxidil $(75 \mu \mathrm{M})$ were treated with cells for $96 \mathrm{~h}$. To investigate whether the cell proliferation was regulated through the KATP channel opening, the cells were pretreated with or without $2 \mathrm{mM}$ TEA for $2 \mathrm{~h}$ and then treated with $U$. peterseniana extract $(0.1,1,10$, and $100 \mu \mathrm{g} / \mathrm{mL})$ and $75 \mu \mathrm{M}$ of minoxidil. After $96 \mathrm{~h}$, MTT $(0.1 \mathrm{mg})$ was added to each well, and the cells were cultured at $37{ }^{\circ} \mathrm{C}$ in a $5 \% \mathrm{CO}_{2} / 95 \%$ air for $4 \mathrm{~h}$. In sequence, the media was carefully discarded and $200 \mu \mathrm{L}$ of DMSO was added to the well. The optical density was measured at $540 \mathrm{~nm}$ on a Versamax microplate reader (Molecular Devices, Sunnyvale, CA, USA). All experiments were repeated at least three times and the results were expressed as the percentage change compared to the average absorbance of the vehicle-treated controls.

\subsection{Proliferation Assay of Dermal Papilla Cells}

The MTT assay was used to determine the cell proliferation as described previously [50]. The MTT assays were performed as follows: dermal papilla cells were seeded at 2000 cells per well in 96-well plates in DMEM supplemented with 1\% FBS. The cells were incubated for $24 \mathrm{~h}$ to allow attachment, and were stimulated with $U$. peterseniana extract $(0.1,1$, and $10 \mu \mathrm{g} / \mathrm{mL})$ or $10 \mu \mathrm{M}$ minoxidil. After $96 \mathrm{~h}$, MTT $(0.1 \mathrm{mg})$ was added to each well, and the cells were cultured at $37^{\circ} \mathrm{C}$ in a $5 \% \mathrm{CO}_{2} / 95 \%$ air for $4 \mathrm{~h}$. Next, the media was carefully discarded and $200 \mu \mathrm{L}$ of DMSO was added to the well. The optical density was measured at $540 \mathrm{~nm}$ on a Versamax microplate reader (Molecular Devices, Sunnyvale, CA, USA). All experiments were repeated at least three times and the results were expressed as the percentage change compared to the average absorbance of the vehicle-treated controls.

\subsection{Western Blot Analysis}

The dermal papilla cells were seeded at $1.0 \times 10^{6}$ cells per $100-\mathrm{mm}$ dish in DMEM supplemented with $1 \% \mathrm{FBS}$ and the cells were cultured at $37^{\circ} \mathrm{C}$ in a $5 \% \mathrm{CO}_{2} / 95 \%$ air. After $24 \mathrm{~h}$, the cells were treated with $U$. peterseniana extract $(0.1,1$, and $10 \mu \mathrm{g} / \mathrm{mL})$ and $10 \mu \mathrm{M}$ minoxidil. The cells were lysed and the protein concentration was determined using a Bio-rad protein assay dye, based on the Bradford method [51]. The proteins (20 30 $\mu \mathrm{g} /$ well) were separated on 10 12\% SDS-PAGE gels and then transferred onto PVDF membranes. After blocking with 5\% nonfat dried milk in TBS containing $0.1 \%$ Tween- 20 (TBST), each membrane was incubated with specific primary antibodies (Table 1) overnight at $4{ }^{\circ} \mathrm{C}$. The membranes were washed six times with TBST and incubated with HRP-conjugated secondary antibody $(1: 5000)$ at $25{ }^{\circ} \mathrm{C}$ for $1 \mathrm{~h}$. The antigen/antibody complexes visualized using West-zol ${ }^{\mathrm{TM}}$ Plus and the Image $\mathrm{J}$ software were used to quantify the intensity of the band [52].

Table 1. List of antibodies used for immunoblotting.

\begin{tabular}{cccc}
\hline Antibodies & Supplier & Species & dilution \\
\hline phospho-(ser552)- $\beta$-catenin & Cell Signaling & Rabbit & $1: 1000$ \\
phospho-(ser675)- $\beta$-catenin & Cell Signaling & Rabbit & $1: 1000$ \\
$\beta$-catenin & Santa Cruz & Rabbit & $1: 2000$ \\
phospho(ser9)-GSK-3 $\beta$ & Cell Signaling & Rabbit & $1: 1000$ \\
GSK-3 $\beta$ & Cell Signaling & Rabbit & $1: 1000$ \\
phospho-Erk1/2 & Cell Signaling & Rabbit & $1: 1000$ \\
Cyclin D1 & BD Biosciences & Mouse & $1: 1000$ \\
phospho(ser780)-pRB & Cell Signaling & Rabbit & $1: 1000$ \\
Cyclin E & Santa Cruz & Rabbit & $1: 1000$ \\
phospho-CDK2 & Cell Signaling & Rabbit & $1: 1000$ \\
CDK2 & Santa Cruz & Rabbit & $1: 1000$ \\
$\beta$-actin & Sigma-Aldrich & Mouse & $1: 5000$ \\
\hline
\end{tabular}




\subsection{Statistical Analysis}

Data were expressed as the mean \pm standard deviation (SD) or standard error (SE) of at least triplicate experiments. The statistical differences between experimental and control groups were estimated using Student's $t$-test. The statistical analysis was performed using SigmaStat Software ver. 3.5 (San Jose, CA, USA). A $p$-value $<0.05$ was considered statistically significant.

Acknowledgments: This work was supported by the project titled "Development of Product and Material Promoting Hair-Growth from Jeju Marine Algae" funded by the Ministry of Land, Transport and Maritime Affairs, Korea, and by the Basic Science Research Program through the National Research Foundation of Korea (NRF), funded by the Ministry of Education (NRF-2016R1D1A1B01010337).

Author Contributions: Jung-Il Kang and Hee-Kyoung Kang conceived and designed the experiments; Jung-Il Kang, Min-Kyoung Kim, and Ji-Hyeok Lee performed the experiments; Jung-Il Kang and Soon-Young Kwon analyzed the data; Eun-Kyoung Hwang, You-Jin Jeon, Young-Sang Koh, Jin-Won Hyun, and Eun-Sook Yoo contributed reagents, materials, and analysis tools; Jung-Il Kang and Hee-Kyoung Kang wrote the paper.

Conflicts of Interest: The authors declare no conflicts of interest.

\section{References}

1. Hunt, N.; McHale, S. The psychological impact of alopecia. BMJ 2005, 331, 951-953.

2. Daniells, S.; Hardy, G. Hair loss in long-term or home parenteral nutrition: Are micronutrient deficiencies to blame? Curr. Opin. Clin. Nutr. Metab. Care 2010, 13, 690-697.

3. Cotsarelis, G.; Millar, S.E. Towards a molecular understanding of hair loss and its treatment. Trends Mol. Med. 2001, 7, 293-301.

4. Burton, J.L.; Marshall, A. Hypertrichosis due to minoxidil. Br. J. Dermatol. 1979, 101, 593-595.

5. Kaufman, K.D.; Olsen, E.A.; Whiting, D.; Savin, R.; DeVillez, R.; Bergfeld, W.; Price, V.H.; Van Neste, D.; Roberts, J.L.; Hordinsky, M.; et al. Finasteride in the treatment of men with androgenetic alopecia. Finasteride male pattern hair loss study group. J. Am. Acad. Dermatol. 1998, 39, 578-589.

6. Rossi, A.; Anzalone, A.; Fortuna, M.C.; Caro, G.; Garelli, V.; Pranteda, G.; Carlesimo, M. Multi-therapies in androgenetic alopecia: Review and clinical experiences. Dermatol. Ther. 2016, 29, 424-432.

7. Tu, H.Y.; Zini, A. Finasteride-induced secondary infertility associated with sperm DNA damage. Fertil. Steril. 2011, 95, 2125.e13-2125.e14.

8. Muller-Rover, S.; Handjiski, B.; van der Veen, C.; Eichmuller, S.; Foitzik, K.; McKay, I.A.; Stenn, K.S.; Paus, R. A comprehensive guide for the accurate classification of murine hair follicles in distinct hair cycle stages. J. Investig. Dermatol. 2001, 117, 3-15.

9. Wang, A.B.; Zhang, Y.V.; Tumbar, T. Gata6 promotes hair follicle progenitor cell renewal by genome maintenance during proliferation. EMBO J. 2017, 36, 61-78.

10. Greco, V.; Chen, T.; Rendl, M.; Schober, M.; Pasolli, H.A.; Stokes, N.; Dela Cruz-Racelis, J.; Fuchs, E. A two-step mechanism for stem cell activation during hair regeneration. Cell Stem Cell 2009, 4, 155-169.

11. Kwack, M.H.; Kang, B.M.; Kim, M.K.; Kim, J.C.; Sung, Y.K. Minoxidil activates beta-catenin pathway in human dermal papilla cells: A possible explanation for its anagen prolongation effect. J. Dermatol. Sci. 2011, 62, 154-159.

12. Dastan, M.; Najafzadeh, N.; Abedelahi, A.; Sarvi, M.; Niapour, A. Human platelet lysate versus minoxidil stimulates hair growth by activating anagen promoting signaling pathways. Biomed. Pharmacother. 2016, 84, 979-986.

13. Kang, J.I.; Kim, S.C.; Hyun, J.H.; Kang, J.H.; Park, D.B.; Lee, Y.J.; Yoo, E.S.; Kang, H.K. Promotion effect of Schisandra nigra on the growth of hair. Eur. J. Dermatol. 2009, 19, 119-125.

14. Ouji, Y.; Yoshikawa, M.; Moriya, K.; Nishiofuku, M.; Matsuda, R.; Ishizaka, S. Wnt-10b, uniquely among Wnts, promotes epithelial differentiation and shaft growth. Biochem. Biophys. Res. Commun. 2008, 367, 299-304.

15. Huelsken, J.; Vogel, R.; Erdmann, B.; Cotsarelis, G.; Birchmeier, W. $\beta$-catenin controls hair follicle morphogenesis and stem cell differentiation in the skin. Cell 2001, 105, 533-545.

16. Molavi, O.; Narimani, F.; Asiaee, F.; Sharifi, S.; Tarhriz, V.; Shayanfar, A.; Hejazi, M.; Lai, R. Silibinin sensitizes chemo-resistant breast cancer cells to chemotherapy. Pharm. Biol. 2017, 55, 729-739. 
17. Gunda, V.; Sarosiek, K.A.; Brauner E.; Kim, Y.S.; Amin, S.; Zhou, Z.; Letai, A.; Parangi, S. Inhibition of MAPKinase pathway sensitizes thyroid cancer cells to ABT-737 induced apoptosis. Cancer Lett. 2017, 395, $1-10$.

18. Li, W.; Man, X.Y.; Li, C.M.; Chen, J.Q.; Zhou, J.; Cai, S.Q.; Lu, Z.F.; Zheng, M. VEGF induces proliferation of human hair follicle dermal papilla cells through VEGFR-2-mediated activation of ERK. Exp. Cell Res. 2012, 318, 1633-1640.

19. Hwang, K.A.; Hwang, Y.L.; Lee, M.H.; Kim, N.R.; Roh, S.S.; Lee, Y.; Kim, C.D.; Lee, J.H.; Choi, K.C. Adenosine stimulates growth of dermal papilla and lengthens the anagen phase by increasing the cysteine level via fibroblast growth factors 2 and 7 in an organ culture of mouse vibrissae hair follicles. Int. J. Mol. Med. 2012, 29, 195-201.

20. Hwang, E.K.; Gong, Y.G.; Park, C.S. Cultivation of a brown alga, Undariopsis peterseniana (Kjellman) Miyabe and Okamura, as a warm-temperature species by artificial seed production in Korea. J. Appl. Phycol. 2011, 23, 449-455.

21. Hwang, E.K.; Gong, Y.G.; Park, C.S. Cultivation of a hybrid of free-living gametophytes between Undariopsis peterseniana and Undaria pinnatifida: Morphological aspects and cultivation period. J. Appl. Phycol. 2012, 24, 401-408.

22. Cho, M.; Yoon, S.J.; Kim, Y.-B. The nutritional composition and antioxidant activity from Undariopsis peterseniana. Ocean Polar Res. 2013, 35, 273-280.

23. Philpott, M.P.; Kealey, T. Cyclical changes in rat vibrissa follicles maintained in vitro. J. Investig. Dermatol. 2000, 115, 1152-1155.

24. Ohnemus, U.; Uenalan, M.; Conrad, F.; Handjiski, B.; Mecklenburg, L.; Nakamura, M.; Inzunza, J.; Gustafsson, J.A.; Paus, R. Hair cycle control by estrogens: Catagen induction via estrogen receptor (ER)- $\alpha$ is checked by ER $\beta$ signaling. Endocrinology 2005, 146, 1214-1225.

25. Sawaya, M.E.; Price, V.H. Different levels of $5 \alpha$-reductase type I and II, aromatase, and androgen receptor in hair follicles of women and men with androgenetic alopecia. J. Investig. Dermatol. 1997, 109, $296-300$.

26. Sanders, D.A.; Fiddes, I.; Thompson, D.M.; Philpott, M.P.; Westgate, G.E.; Kealey, T. In the absence of streptomycin, minoxidil potentiates the mitogenic effects of fetal calf serum, insulin-like growth factor 1, and platelet-derived growth factor on NIH $3 \mathrm{~T} 3$ fibroblasts in a $\mathrm{K}+$ channel-dependent fashion. J. Investig. Dermatol. 1996, 107, 229-234.

27. Whittaker, S.R.; Mallinger, A.; Workman, P.; Clarke, P.A. Inhibitors of cyclin-dependent kinases as cancer therapeutics. Pharmacol. Ther. 2017, 173, 83-105.

28. Leirós, G.J.; Ceruti, J.M.; Castellanos, M.L.; Kusinsky, A.G.; Balañá, M.E. Androgens modify Wnt agonists/antagonists expression balance in dermal papilla cells preventing hair follicle stem cell differentiation in androgenetic alopecia. Mol. Cell. Endocrinol. 2017, 439, $26-34$.

29. Whelchel, A.; Evans, J.; Posada, J. Inhibition of ERK activation attenuates endothelin-stimulated airway smooth muscle cell proliferation. Am. J. Respir. Cell Mol. Biol. 1997, 16, 589-596.

30. Dallob, A.L.; Sadick, N.S.; Unger, W.; Lipert, S.; Geissler, L.A.; Gregoire, S.L.; Nguyen, H.H.; Moore, E.C.; Tanaka, W.K. The effect of finasteride, a $5 \alpha$-reductase inhibitor, on scalp skin testosterone and dihydrotestosterone concentrations in patients with male pattern baldness. J. Clin. Endocrinol. Metab. 1994, 79, 703-706.

31. Lee, J.-H.; Ko, J.-Y.; Kim, E.-A.; Hwang, E.-K.; Park, C.S.; Lee, J.-S.; Kim, C.-Y.; Lee, H.-S.; Kang, H.-K.; Cha, S.-H. Identification and large isolation of an anti-inflammatory compound from an edible brown seaweed, Undariopsis peterseniana, and evaluation on its anti-inflammatory effect in in vitro and in vivo zebrafish. J. Appl. Phycol. 2016, 1-10, doi:10.1007/s10811-016-1012-3.

32. Kang, J.I.; Yoo, E.S.; Hyun, J.W.; Koh, Y.S.; Lee, N.H.; Ko, M.H.; Ko, C.S.; Kang, H.K. Promotion effect of apo-9'-fucoxanthinone from sargassum muticum on hair growth via the activation of Wnt $/ \beta$-catenin and VEGF-R2. Biol. Pharm. Bull. 2016, 39, 1273-1283.

33. Shorter, K.; Farjo, N.P.; Picksley, S.M.; Randall, V.A. Human hair follicles contain two forms of ATP-sensitive potassium channels, only one of which is sensitive to minoxidil. FASEB J. 2008, 22, 1725-1736.

34. Buhl, A.E.; Waldon, D.J.; Kawabe, T.T.; Holland, J.M. Minoxidil stimulates mouse vibrissae follicles in organ culture. J. Investig. Dermatol. 1989, 92, 315-320.

35. Elliott, K.; Stephenson, T.J.; Messenger, A.G. Differences in hair follicle dermal papilla volume are due to extracellular matrix volume and cell number: Implications for the control of hair follicle size and androgen responses. J. Investig. Dermatol. 1999, 113, 873-877. 
36. Kang, J.I.; Kim, E.J.; Kim, M.K.; Jeon, Y.J.; Kang, S.M.; Koh, Y.S.; Yoo, E.S.; Kang, H.K. The promoting effect of ishige sinicola on hair growth. Mar. Drugs 2013, 11, 1783-1799.

37. Nunez, M.; Medina, V.; Cricco, G.; Croci, M.; Cocca, C.; Rivera, E.; Bergoc, R.; Martin, G. Glibenclamide inhibits cell growth by inducing G0/G1 arrest in the human breast cancer cell line MDA-MB-231. BMC Pharmacol. Toxicol. 2013, 14, 6.

38. Lien, W.H.; Polak, L.; Lin, M.; Lay, K.; Zheng, D.; Fuchs, E. In vivo transcriptional governance of hair follicle stem cells by canonical Wnt regulators. Nat. Cell Biol. 2014, 16, 179-190.

39. Polakis, P. Wnt signaling in cancer. Cold Spring Harb. Perspect. Biol. 2012, 4, a008052.

40. Hedgepeth, C.M.; Conrad, L.J.; Zhang, J.; Huang, H.C.; Lee, V.M.; Klein, P.S. Activation of the Wnt signaling pathway: A molecular mechanism for lithium action. Dev. Biol. 1997, 185, 82-91.

41. Cao, Y.; Lin, M.; Bu, Y.; Ling, H.; He, Y.; Huang, C.; Shen, Y.; Song, B.; Cao, D. p53-inducible long non-coding RNA PICART1 mediates cancer cell proliferation and migration. Int. J. Oncol. 2017, 50, 1671-1682.

42. Shin, H.S.; Park, S.Y.; Hwang, E.S.; Lee, D.G.; Song, H.G.; Mavlonov, G.T.; Yi, T.H. The inductive effect of ginsenoside F2 on hair growth by altering the Wnt signal pathway in telogen mouse skin. Eur. J. Pharmacol. 2014, 730, 82-89.

43. Park, P.J.; Moon, B.S.; Lee, S.H.; Kim, S.N.; Kim, A.R.; Kim, H.J.; Park, W.S.; Choi, K.Y.; Cho, E.G.; Lee, T.R. Hair growth-promoting effect of aconiti ciliare tuber extract mediated by the activation of Wnt/beta-catenin signaling. Life Sci. 2012, 91, 935-943.

44. Hino, S.; Tanji, C.; Nakayama, K.I.; Kikuchi, A. Phosphorylation of $\beta$-catenin by cyclic amp-dependent protein kinase stabilizes $\beta$-catenin through inhibition of its ubiquitination. Mol. Cell. Biol. 2005, 25, 9063-9072.

45. Monick, M.M.; Carter, A.B.; Robeff, P.K.; Flaherty, D.M.; Peterson, M.W.; Hunninghake, G.W. Lipopolysaccharide activates Akt in human alveolar macrophages resulting in nuclear accumulation and transcriptional activity of $\beta$-catenin. J. Immunol. 2001, 166, 4713-4720.

46. Kwon, O.; Han, J.; Yoo, H.; Chung, J.; Cho, K.; Eun, H.; Kim, K. Human hair growth enhancement in vitro by green tea epigallocatechin-3-gallate (EGCG). Phytomedicine 2007, 14, 551-555.

47. Lavoie, J.N.; L'Allemain, G.; Brunet, A.; Müller, R.; Pouysségur, J. Cyclin D1 expression is regulated positively by the p42/p44MAPK and negatively by the p38/HOGMAPK pathway. J. Biol. Chem. 1996, 271, 20608-20616.

48. Picard, F.; Schulz, T.; Hartmann, R.W. 5-phenyl substituted 1-methyl-2-pyridones and 4'-substituted biphenyl-4-carboxylic acids. Synthesis and evaluation as inhibitors of steroid-5 $\alpha$-reductase type 1 and 2. Biorg. Med. Chem. 2002, 10, 437-448.

49. Filsell, W.; Little, J.C.; Stones, A.J.; Granger, S.P.; Bayley, S.A. Transfection of rat dermal papilla cells with a gene encoding a temperature-sensitive polyomavirus large $\mathrm{T}$ antigen generates cell lines retaining a differentiated phenotype. J. Cell Sci. 1994, 107, 1761-1772.

50. Carmichael, J.; DeGraff, W.G.; Gazdar, A.F.; Minna, J.D.; Mitchell, J.B. Evaluation of a tetrazolium-based semiautomated colorimetric assay: Assessment of chemosensitivity testing. Cancer Res. 1987, 47, 936-942.

51. Bradford, M.M. A rapid and sensitive method for the quantitation of microgram quantities of protein utilizing the principle of protein-dye binding. Anal. Biochem. 1976, 72, 248-254.

52. Image J. Image Processing and Analysis in Java. Available online: https://imagej.nih.gov/ij/ (accessed on 10 February 2017).

(C) 2017 by the authors. Submitted for possible open access publication under the terms and conditions of the Creative Commons Attribution (CC BY) license (http://creativecommons.org/licenses/by/4.0/). 